\title{
The Monetary Transmission Mechanism: An SVAR Analysis of the Four Municipalities in China
}

\author{
Lili $\mathrm{Wu}^{1} \&$ Mingxu $\mathrm{Li}^{1}$ \\ ${ }^{1}$ School of Business and Administration, China University of Petroleum - Beijing, Beijing, China \\ Correspondence: Lili Wu, School of Business and Administration, China University of Petroleum - Beijing, Beijing, \\ China.
}

Received: December 4, 2017

Accepted: December 22, $2017 \quad$ Available online: December 26, 2017

doi:10.11114/aef.v5i1.2839

URL: https://doi.org/10.11114/aef.v5i1.2839

\begin{abstract}
This paper explores the role of housing markets in the transmission of monetary policy shocks across four Chinese municipalities, namely Beijing, Shanghai, Tianjin, and Chongqing. The analysis is based on identification of housing demand shocks, monetary policy shocks and credit supply shocks through a Structural Vector Autoregressive (SVAR) model estimated using monthly data for four cities from July 2005 to December 2015. The empirical results show great differences in the four cities as far as the housing market is concerned. They also indicate that housing plays a stronger role in the transmission of monetary policy shocks in Beijing and Shanghai than in Tianjin and Chongqing. These results are reasonably robust across several model specifications.
\end{abstract}

Keywords: housing market, consumption, transmission mechanism, SVAR

\section{Introduction}

House prices in China have skyrocketed over the last decade. Since 2002, the average overall annual compound rate of real house prices has been above $10 \%$. Rapid house price appreciation has significantly affected household wealth. In China, housing has become the largest component of household net wealth, representing $41 \%$ of total wealth, which is almost $60 \%$ greater than that of American households ${ }^{1}$. The influence of rising house prices on net wealth is even greater when one considers that housing wealth is levered through mortgages (Elbourne, 2008). Due to the relative amount of household wealth held in housing, attention has increasingly been devoted to understanding the influence of rising house prices on the wealth of individual households.

Like other assets, house prices are affected by changes in interest rates. We argue that when house prices are influenced by interest rates, and consumption depends on housing wealth, a channel of monetary policy transmission develops through house prices. A few papers have focused on the relationship between housing, consumption and interest rates. For example, Elbourne (2008) concludes that in the United Kingdom about 15\% of the decline in consumption following an interest rate shock can be explained by a combined effect of house wealth and monetary effects associated with house price changes. Ncube and Ndou (2011) suggest that in South Africa, consumption declines due to the combined effect of house wealth and credit changes following a monetary policy tightening by $9.8 \%$. Following these studies, this paper aims to identify the effects of short-term interest rate shock on real house price movements in China, and examine the transmission mechanism of housing by analyzing whether fluctuations in real house prices have a significant spillover effect on consumption decisions.

It is well known that consumption is influenced by house price shocks not only at the national, but also at the regional and city level. In fact, local economies and regulations may exert a dominant influence on housing markets. Therefore, in the face of national shocks, local housing markets may exhibit asymmetric responses and play various roles in transmitting the macro shocks to the real economy. However, although the house price transmission effects have been

\footnotetext{
${ }^{1}$ The data come from Borst, N. (2012). Chinese Household Wealth and the Housing Market, from http://www.economonitor.com/piie/2012/03/12/chinese-household-wealth-and-the-housing-market/
} 
examined variously across a number of countries $^{2}$, the evidence from housing markets across regions and cities is sparse.

Recently, Nanda and Yeh (2014) explored international transmission mechanisms and their role in fostering a contagion effect in the housing markets across six major Asian cities. These cities are located in different countries, where the direction, magnitude and timing of monetary policies are various. Therefore, when house prices and consumption exhibit great variety following monetary policy shocks, we cannot know exactly whether this variety stems from differences in shocks or the housing markets per se. Against this backdrop, this analysis sheds light on housing as a transmission mechanism, and particularly it demonstrates how, in China, interest rate shocks at the national level do not exert a uniform influence on consumption across cities. Rather, the housing market in each city plays an important role in influencing changes in household consumption. We examined four cities in China, namely Beijing, Shanghai, Tianjin, and Chongqing. These four municipalities all belong to the highest level classification for cities used by the Chinese government. However, the heterogeneity between these cities is still considerable. Beijing and Shanghai are two first-tier cites in China. With constant inflows of population and capital, these cities experience higher housing demand. Moreover, their more developed financial markets make housing wealth as well as collateral effects may cause consumption behavior to change first in these areas. Tianjin is a rapidly developing economic center. The housing market in this city is not as hot as those in the first-tier cities. However, Tianjin benefits substantially from China's ongoing urbanization, and its housing market has ample opportunities to grow. Finally, the city of Chongqing has experienced increasing economic development. It has absorbed the surplus demand from the first-tier cities, where local governments recently put in place a series of restrictions on housing purchase. However, as the only western city among the four, Chongqing has a housing market with a relatively modest capacity for growth and its market consumption will likely remain lower than in the other three megacities. Due to these heterogeneities in economic environments and housing markets, we believe that the relationship between house prices and the real economy in each city will be quite different. These different outcomes may impair the efficacy of policies. This is why it is important to study these markets: they provide an important case study for testing domestic macroeconomic influences on regional housing markets.

In order to provide a systematic empirical analysis of how house prices respond to shocks and transmit their effects to the real economy in four Chinese municipalities, we utilized a structural autoregressive (SVAR) framework. SVAR is commonly used in identifying effects of various macro shocks on housing market transmission (Bjornland \& Jacobsen, 2010; Elbourne, 2008; M. Iacoviello, 2000; Lastrapes, 2002; Musso, Neri, \& Stracca, 2011; Ncube \& Ndou, 2011; Pedram, Shirinbakhsh, \& Afshar, 2011). Using a framework that includes six variables-consumer prices, private consumption, house prices, residential investment, interest rates and residential development loans-this paper incorporates housing demand shocks, monetary policy shocks and credit supply shocks into a statistical model and imposes a number of contemporaneous restrictions according to eligible economic theories and econometric considerations. In order to obtain comparable results for these four markets, the same SVAR model is estimated on the four cities over a sample period from 2005 to 2015, and the impulse responses in these markets are compared to understand the similarities and the differences in a systematic manner.

The remainder of this paper is organized as follows: Section 2 outlines the SVAR model and lays out the econometric methodology. Section 3 describes the data and their time-series properties. Section 4 presents the main impulse responses results. Finally, Section 5 concludes.

\section{Methodology}

This section will specify a SVAR model. This model uses the restrictions imposed by economic theory to identify the system.

\subsection{The SVAR Model}

The dynamics of the SVAR are modeled using the VAR, in which each variable is expressed as a function of its own lags as well as the lags of all other variables in the system. Let $z_{t}=\left(z_{i t}, \cdots z_{k t}, \cdots z_{k t}\right)$ ' be a $K \times 1$ vector of endogenous variables, a $p$-th order VAR is defined as

$$
z_{t}=v+A_{1} z_{t-1}+\cdots+A_{p} z_{t-p}+u_{t}
$$

${ }^{2}$ Previous literatures include the studies in the United States (see for example Green (1997), Case, Quigley, and Shiller (2005), Ghent and Owyang (2010), Jarocinski and Smets (2008), Vargas-Silva (2008), Ghent and Owyang (2010), Pavlidis, Paya, Peel, and Spiru (2009), Matteo Iacoviello and Neri (2010)), in UK (see for example Gilchrist (2002), Elbourne (2008), Attanasio, Leicester, and Wakefield (2011), Narayan and Narayan (2011), Gilchrist (2002)) and other countries (see Muellbauer and Murphy (2008), Bassanetti and Zollino (2010), Bulligan (2010), Peretti, Gupta, and Inglesi-Lotz (2012), Calcagno, Fornero, and Rossi (2009), Ludwig and Slok (2004), Giuliodori (2005), Phang (2004)). 
where $\mathbf{v}_{\mathbf{t}}$ is a $K \times 1$ vector of constants, $\mathbf{A}_{\mathbf{i}}$ are $K \times K$ coefficient matrices for $i=1, \cdots, p$, and $\mathbf{u}_{\mathbf{t}}$ is a $K$ -dimensional process and $\mathbf{u}_{\mathbf{t}} \sim N(\mathbf{0}, \mathbf{\Omega})$

This $\operatorname{VAR}(p)$ can be interpreted as a reduced form model. Specifically, those reduced form innovations $\mathbf{u}_{\mathbf{t}}$ are observable but have no direct economic interpretation. The idea behind the SVAR procedure is to use the reduced-form model (1), together with the bare minimum of economic theory, to back out structural shocks and the responses to those shocks. A SVAR model of order $p$ can be defined as

$$
A z_{t}=\mathbf{Y}+A^{*} z_{t-1}+\cdots+A^{*} z_{t-p}+B \varepsilon_{t}
$$

where $\gamma$ is a $K \times 1$ vector of constants, $\mathrm{A}^{*}{ }_{\mathrm{i}}$ are $K \times K$ coefficient matrices for $i=1, \cdots p$, and $\boldsymbol{\varepsilon}_{\mathrm{t}}$ is $K$-dimensional vector of structural innovations with $\varepsilon_{\mathrm{t}}{ }^{\sim} N(0 \boldsymbol{\Sigma})$. Here the matrix $\mathrm{A}$ is used to model the contemporaneous relationships, while the matrix B contains structural form parameters of the model.

Since shocks cannot be observed directly, the common practice to identify structural shocks is to left-multiply the SVAR with $\mathbf{A}^{-1}$, leading to the following reduced form

$$
\mathbf{z}_{\mathrm{t}}=\mathrm{A}^{-1} \mathbf{Y}+\mathrm{A}^{-1} \mathrm{~A}^{*}{ }_{1 z_{\mathrm{t}-1}}+\cdots+\mathrm{A}^{-1} \mathrm{~A}^{*} \mathrm{p}_{\mathrm{t}-\mathrm{p}}+\mathrm{A}^{-\mathrm{B}} \mathrm{B} \boldsymbol{\varepsilon}_{t}
$$

which can be linked to equation (1) by letting $\mathrm{A}^{-1} \mathbf{Y}=\mathrm{v}, \mathrm{A}^{-1} \mathrm{~A}^{*}{ }_{\mathrm{i}}=\mathrm{A}_{\mathrm{i}}$ for $i=1, \cdots p$. Thus, the relation between the reduced-form disturbances and the structural form innovation is expressed as:

$$
\mathrm{u}_{\mathrm{t}}=\mathrm{A}^{-1} \mathrm{~B} \varepsilon_{\mathrm{t}}
$$

and

$$
\mathbf{\Omega}=\mathrm{A}^{-1} \mathrm{~B} \Sigma \mathrm{B}^{\prime} \mathrm{A}^{-1}
$$

where $\boldsymbol{\Omega}$ is the maximum likelihood estimator of the reduced form model with a rank $K$. An estimate of $\mathbf{\Omega}$ can be obtained by estimating the VAR model and the maximum number of non-redundant elements of $\hat{\mathbf{\Omega}}$ is $K(K+1) / 2$. Since the overall number of elements in the structural form matrices $\mathrm{A}$ and $\mathrm{B}$ is $2 K^{2}$, therefore at least $2 K^{2}-K(K+1) / 2$ further restrictions need to be imposed to identify the full model.

\subsection{Identification}

The SVAR modeling requires a prudent choice of variables and use restrictions on shocks to obtain economic interpretative function of the impulse response. Hence, in this SVAR model, we specify six dimensional VAR with $\mathbf{z}_{\mathbf{t}}=\left[\begin{array}{llllll}p_{t} & c_{t} & r i_{t} & h p_{t} & r_{t} & b_{t}\end{array}\right]^{\prime}$, where $\mathbf{z}_{\mathbf{t}}$ is a vector comprising consumer prices $\left(p_{t}\right)$, private consumption $\left(c_{t}\right)$, residential investment $\left(r i_{t}\right)$, house prices $\left(h p_{t}\right)$, 3-month interbank interest rate $\left(r_{t}\right)$ and residential development loans $\left(l_{t}\right)$.

In order to identify the three shocks which we are interested in, namely monetary policy shocks, housing demand shocks and credit supply shocks, the baseline model for SVAR estimation is defined as follows

$$
\left[\begin{array}{cccccc}
1 & 0 & 0 & 0 & 0 & 0 \\
a_{21} & 1 & 0 & 0 & 0 & 0 \\
a_{31} & a_{32} & 1 & 0 & 0 & 0 \\
a_{41} & a_{42} & a_{43} & 1 & 0 & 0 \\
a_{51} & a_{52} & a_{53} & a_{54} & 1 & 0 \\
a_{61} & a_{62} & a_{63} & a_{64} & a_{65} & 1
\end{array}\right]\left[\begin{array}{c}
u_{t}^{p} \\
u_{t}^{c} \\
u_{t}^{r i} \\
u_{t}^{h p} \\
u_{t}^{r} \\
u_{t}^{l}
\end{array}\right]=\left[\begin{array}{cccccc}
b_{11} & 0 & 0 & 0 & 0 & 0 \\
0 & b_{22} & 0 & 0 & 0 & 0 \\
0 & 0 & b_{33} & 0 & 0 & 0 \\
0 & 0 & 0 & b_{44} & 0 & 0 \\
0 & 0 & 0 & 0 & b_{55} & 0 \\
0 & 0 & 0 & 0 & 0 & b_{66}
\end{array}\right]\left[\begin{array}{c}
\varepsilon_{t}^{p} \\
\varepsilon_{t}^{c} \\
\varepsilon_{t}^{r i} \\
\varepsilon_{t}^{h p} \\
\varepsilon_{t}^{r} \\
\varepsilon_{t}^{l}
\end{array}\right]
$$

Here $\varepsilon_{t}^{p}$ is a consumer price shock, $\varepsilon_{t}^{c}$ is a private consumption shock, $\varepsilon_{t}^{r i}$ is a residental investment shock, $\varepsilon_{t}^{h p}$ is a housing demand shock, $\varepsilon_{t}^{r}$ is a monetary supply shock and $\varepsilon_{t}^{l}$ is a credit supply shock. The reduced form errors are denoted similarly except with $u_{t}^{r}$, an interest rate error, and $u_{t}^{l}$, a residential development loan error. The whole structural model can be decomposed into three separate blocks: the demestic goods market block, the housing market block and the policy block.

The first two equations describe the domestic goods market equilibrium by representing aggregate supply and aggregate demand respectively. Price shocks in the first row are under the assumption of sticky prices in short run. It is asumed that other shocks in the system do not affect consumer prices within a month, though changes in consumer prices do affect the remaining variables in the same month. For example, private consumption in the second row is allowed to react immediately to price shocks. As previously discussed, a housing shock can affect private consumption in several ways. But a housing demand shock, represented by an increase in real house prices, leads to a rise in consumption 
through time.

Rows 3 and 4 comprise the housing market equilibrium. In the housing market, note that the equation for real house prices in the SVAR can be interpreted as a housing demand function, relating this variable instantaneously to housing supply. It is conceivable that an increase in residential investment instantaneously increases the amount of new housing, which creates downward pressure on the real price of housing through an outward shift in the housing supply curve. Shocks from the goods market also have instantaneous effects on real house prices. An increase in inflation, for example, leads to a fall in real income, which is likely to have an immediate negative effect on house prices by influencing consumer spending pattens.

Rows 5 and 6 represent government policy shocks, with row 5 representing a monetary policy shock and row 6 representing a credit supply shock. For the monetary policy shock, it is assumed that the short-term interest rate does not react to credit supply in the same month, which appears to be realistic.

We have tried alternative identification schemes. While the results for these alternative identification schemes give similar results, none of them seem superior to the above identification.

\section{Properties of the Data}

\subsection{Data}

To estimate the strategy discussed above, this paper uses data from July 2005, when the monthly house price index data became available, through December 2015. Since the dataset is not sufficiently long, we use monthly data, instead of quarterly data employed by the majority of earlier studies, to avoid suffering from considerable size distortion and a reduction in degrees of freedom.

In the data series, inflation $\left(p_{t}\right)$ is the consumer price index (base=1999). Private consumption $\left(c_{t}\right)$ is the total retail sales of consumer goods. Short-term interest rate $\left(r_{t}\right)$ is chosen as the 3-month interbank rate because it has been traded actively and is commonly used as a benchmark for pricing other financial assets (Porter \& Xu, 2009). Residential development loans $\left(l_{t}\right)$ is the total real estate development investment financing minus the self-funded part, consisting of domestic bank loans, foreign invested funds and other funds. All of these financing channels embody a kind of credit support. The house price data is from the Price Indices of Residential Buildings in 70 Cities ("the 70 Cities Index"). This index has been published by the NBS since 1998. It was published quarterly before July 2005 and since then it has been published monthly. This index uses a consistent information collection method, so it is comparable between years. The data are all from the Wind Information. Real terms of these variables are obtained by deflating using the CPI. The Census X12-ARIMA method is used to seasonally adjust the raw data. Seasonal adjustment is not applied to interest rates or to inflation. The interbank interest rate enters the model in level, the rest enter in natural logarithms.

\subsection{Unit Root Tests and Cointegration Tests}

Before estimating the reduced VAR form, a unit root test is performed using the Augmented Dickey Full (ADF) and Phillips-Person (PP) test. The results show that all variables have unit roots whereas the first differenced variables are confirmed to be stationary.

In order to properly specify the unrestricted VAR, it is import to test for cointegration of the hypothesized unit root variables. To that end, Johansen's maximum likelihood test with small sample adjustment is applied here. Table 1 shows the number of cointegration equations by both trace test and eigenvalue test at 0.05 level. The results show that there is compelling evidence for the existence of cointegrating relationships in this system. According to the result of Sims, Stock, and Watson (1990), if variables are cointegrated, a VAR in first differences would be misspecified since it omits error-correction mechanisms. Because the primary focus of this study is on the short-run dynamics of the system, and the purpose of the estimation is to examine the interrelationships among the variables through the impulse response functions, rather than the significance of individual coefficients, we will estimate the model in levels.

Table 1. Johansen Multivariate Cointegration Test

\begin{tabular}{lcc}
\hline & $\lambda_{\text {trace }}$ & $\lambda_{\max }$ \\
\hline Beijing & 2 & 2 \\
Tianjin & 2 & 2 \\
Shanghai & 2 & 1 \\
Chongqing & 2 & 2 \\
\hline
\end{tabular}




\section{Empirical Evidence}

This section looks at the econometric results of the specification. The purpose of this section is to compare the responses of the four cities following a shock. Figure 1 reports the responses of the variables included in the SVAR model to selected shocks: housing demand shocks, monetary policy shocks and credit supply shocks. Each panel displays the estimated response function, along with simulated standard error bands to account for the precision of the estimates. The dotted lines in each panel represent the upper and the lower bands of $90 \%$ bootstrapped confidence intervals computed using 2000 repetitions of Kilian's method. The results are summarized in Table 2, which reports the signs of the impulse responses to identified structural shocks in each city.

\subsection{Housing Demand Shock}

A positive housing demand shock is defined as an increase in real house prices that leads to a rise in residential investment over time (Matteo Iacoviello \& Neri, 2010; Jarocinski \& Smets, 2008). Impulse responses to a housing demand shock of one-SD deviation of innovation generally show expected features, though not for all variables in all cities.

Without exception, housing demand shocks have a positive impact on the consumer price in all four cities. Consumer price displays the commonly found hump shaped response with a peak effect of $0.11 \%$ to $0.20 \%$ occurring after 10 months; it then returns to a new steady state which is higher than the initial baseline, showing that housing demand shocks have a permanent influence on general price levels.

Real house prices increase on impact from $0.7 \%$ to $1.1 \%$ depending on cities and fall back very slowly to their baseline, reaching it after one to one and a half years. Such a pattern is consistent with strong autocorrelation in house prices, resulting in part from extrapolative expectations (Andre, 2010).

The most important effect of a housing demand shock lies in its impact on residential investment. Although housing demand shocks have positive impacts on residential investment in all cites, the magnitudes differ. It is found that residential investment is more reactive in Beijing and Shanghai than in Tianjin and Chongqing. In Beijing and Shanghai, the initial effects are positive and the pattern represents a common inversed $\mathrm{U}$ shape, with a peak of $4.2 \%$ and $2.8 \%$ respectively. However, in Tianjin and Chongqing, a one-time positive shock to house prices influences residential investment adversely over the first five months, and then influences it positively, concluding with a slight increase above the baseline.

A house price shock can affect private consumption through a rise in residential investment, which produces multiplier effects on employment and income, as residential investment represents over 15\% of GDP on average across cities and time. Besides this, a housing shock can affect private consumption through wealth effect, or more precisely, a collateral or liquidity effect. This housing wealth or collateral effect is expected to be stronger in economies with more sophisticated markets. Figure 1 shows that the initial private consumption response is roughly positive in Beijing and Shanghai, which is as expected, given that housing wealth effects exert a dominant influence on private consumption. In Tianjin and Chongqing, however, the initial private consumption response is negative, showing that house price increases crowd out private consumption, at least in short run. As time goes by, the negative response turns positive in these two cities. In all four cities, the positive response of private consumption is long-lived and significant. This is not unexpected. For many people, including home-owners, permanent changes in wealth lead to permanent changes in consumption.

\subsection{Monetary Policy Shock}

Figure 1 presents the responses of the endogenous variables to a contractionary monetary policy (interest rate) shock in all cities. The responses are generally in line with the predictions of economic theory, although there are some exceptions.

In all cities, a large effect in housing market related variables is found, particularly in residential investment. This evidence is consistent with previous work showing that the largest effect of a monetary policy shock is on residential investment (see Erceg and Levin (2006) and Vargas-Silva (2008). However, this effect varies in size, shape and duration across cities. In all cities but Beijing, residential investment falls immediately following the increase in the opportunity cost of investment. It then rises and returns to baseline at around 4 months. In Beijing, however, residential investment increases instantaneously and then returns to baseline at around 5 months.

There is evidence of a price puzzle in the short term in all cities: after a contractionary monetary policy shock, consumer prices initially increase rather than decrease in all cities. But consumer prices are less sensitive than house prices to monetary innovation. In all cities, house prices decrease significantly for several months before increasing and returning to their baselines. This happens because when a central bank unexpectedly raises the short-turn interest rate, the mortgage interest rates charged by commercial banks should raise. A rise in interest rates increases the cost of 
borrowing, thus leading to a reduction in demand, particularly in interest-sensitive sectors of the economy, such as housing. One can expect a user cost effect to reduce relative demand for housing, and this general fall in demand will result in a fall in house prices. Only when interest rates are back to the baseline will the real house prices go up. Figure 1 suggests a negative correlation between behavior of interest rates and behavior of real house prices. In response to a contractionary monetary policy shock, real house prices significantly decrease in virtually all cities, but Beijing experiences the biggest house price fluctuation whereas Tianjin and Chongqing are probably at the other extreme, with Shanghai somewhere in between: one would expect overshooting of house prices in a perfect market.

The response of private consumption is also well pronounced. In all cities, private consumption declines gradually. In Beijing and Shanghai, the fall displays the commonly found hump shape with a peak effect occurring after 11 months in Beijing and 6 months in Shanghai; the decline persists and is statistically significant over the full 36 months. However, in Tianjin and Chongqing, private consumption decreases to a certain point (around $0.5 \%$ ) following a one-SD increase of interest rate, and then keeps at that level for a very long time, rather than gradually going back to the baseline. Although the decline is more durable in Tianjin and Chongqing, it is not statistically significant.

Our main purpose is to investigate the role of housing market in the transmission of monetary policy. For this purpose, we can look at the effects of a monetary shock on house prices and then see how much consumption changes following a house price shock. Take Beijing as a fairly representative case. Figure 1 shows that the maximum decline of private consumption in response to a one-SD increase in interest rate is $0.57 \%$. It also shows that the maximum decline of house prices in response to a one-SD increase in interest rate is $0.87 \%$, and a one-SD $(0.59 \%)$ increase in real house price leads to $0.2 \%$ increase in private consumption. We can gauge the role played by house prices by combining these two effects, i.e. the decrease of house prices by $0.87 \%$ following a monetary policy shock will trigger private consumption to decrease by $0.29 \%^{3}$, which accounts for about $51.7 \%$ of the total $0.57 \%$ fall in consumption, showing that over half of the fall in consumption is due to the changing house prices.

We can gauge the role played by house prices in other cities the same way. The corresponding numbers are $53.2 \%, 44.5 \%$ and $17.7 \%$ in Shanghai, Tianjin, and Chongqing respectively.

The different responses can be justified as follows: cities with high loan-to-value ratios, a large owner-occupied sector and a large proportion of variable-interest mortgage loans should experience relatively high real house price volatility and a great role for housing in the interest rate transmission mechanism.

Overall, the evidence presented here is consistent with the view that the transmission of monetary policy shocks to the housing market and private consumption is stronger in the Beijing and Shanghai than in other cities.

\subsection{Credit Supply Shock}

In response to a credit supply shock, initially the consumer price significantly rises in all four cities: the maximum point estimate ranges from $1.5 \%$ in Shanghai to $2.7 \%$ in Beijing; then it stabilizes at its higher steady state level.

The initial effect on private consumption is positive for all cities except Chongqing, where the private consumption falls below baseline for the first 12 months. Shanghai has the greatest response, with private consumption rising sharply by $3.8 \%$ within two months of the shock and stabilizing at a $0.32 \%$ increase. In Beijing and Tianjin, private consumption shows a similar increase in magnitude and persistence. In these cities, immediately following a shock, private consumption rises to around $2 \%$, oscillates, and then stays at a new steady state about $1 \%$ higher than the baseline level. However, the response of consumption in Tianjin is not statistically significant.

In all cities but Tianjin, residential investment increases immediately and significantly in response to a credit supply shock. In Beijing and Chongqing, residential investment reaches the maximum point 3 months after the shock and then gradually returns to the original baseline, with the increase in residential investment levels lasting over a full one year horizon. In Shanghai, the residential investment increases and oscillates in the first few months following the credit expansion but the effect is not statistically significant. After about 5 months, residential investment starts to increase persistently over two years. In Tianjin, the residential investment falls dramatically below its baseline and stays there for about 4 months. Later, it tends to rise above its initial baseline.

Now, consider how this affects real house prices. In all cities but Tianjin, real house prices exhibit a statistically significant increase over some horizon following the credit expansion. In these three cities, the increase in house prices immediately follows the credit expansion. House prices remain above baseline for at least one year.

\footnotetext{
${ }^{3}$ This number is obtained from $0.87 \% \times(0.2 \% \div 0.59 \%)$. In order to get comparative response, it is necessary to rescale the initial impact on the house prices to be the same (1\%) for all cities, and one-SD of positive house prices shock means $0.59 \%$ increase of house price in Beijing.
} 
Table 2. Signs of the impulse to selected structural shocks

\begin{tabular}{lcccc}
\hline & Beijing & Shanghai & Tianjin & Chongqing \\
\hline House price shock & & & & + \\
Consumer price & + & + & + & + \\
Private consumption & + & + &,+- &,+- \\
Residential investment & + & + & + & 0 \\
Real house prices & + &,+- & + &,+- \\
Residential development debt & - &,+- &,+- &,+- \\
& & & & \\
Monetary shock & & & & \\
Consumer price &,+- &,+- &,+- &,+- \\
Private consumption & - & - & - & - \\
Residential investment &,+- & - &,+- & - \\
Real house prices &,+- & - & - &,+- \\
Residential development debt & - &,+- & - & - \\
& & & &,+ \\
Credit supply shock & + & & + &,+- \\
Consumer price & + & + & + &,+- \\
Private consumption & + & + & + &,+- \\
Residential investment &,+- & + & + & + \\
Real house prices & + & + & + & + \\
Residential development debt & + & + & + & + \\
\hline are & + & & & + \\
\hline
\end{tabular}

Note: "+" and "-." are reported if the impulse response of the corresponding variable is above or below the baseline for at least 6 months at a significance level of $90 \%$.

\section{Beijing}

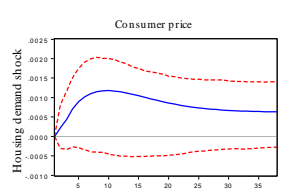

Consumer price

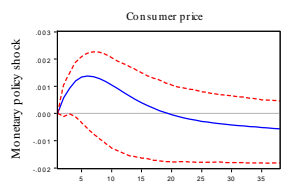

Consumer price

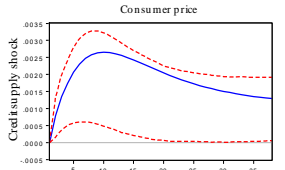

Shanghai
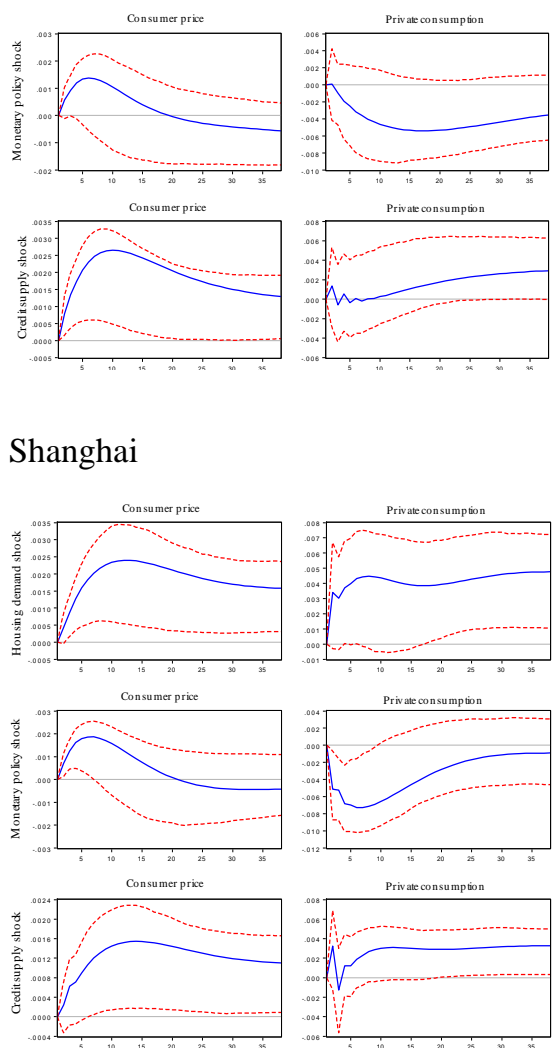

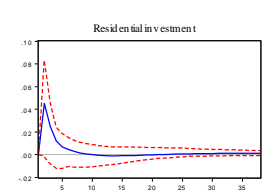

Residen nuli in vestmen

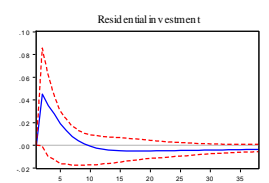

Residential investment
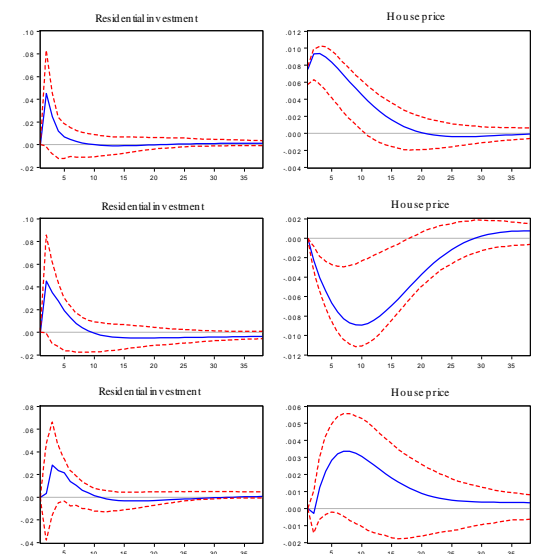

House price

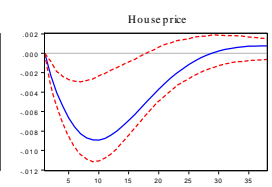

Housep price
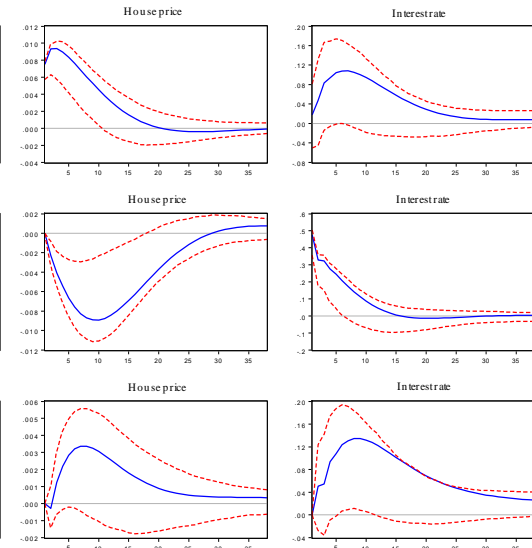

Interestrat

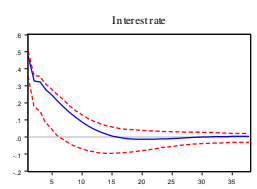

Interestrat
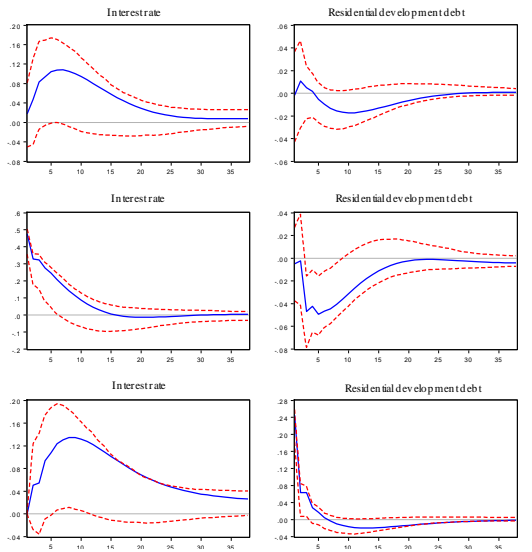
Tianjin

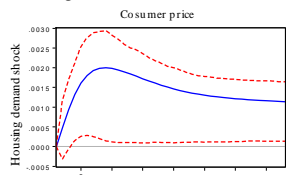

Consumer price

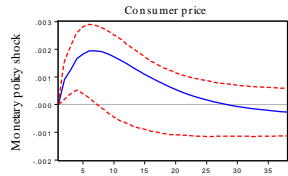

Consumer pric

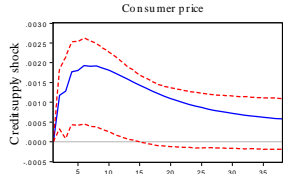

Chongqing

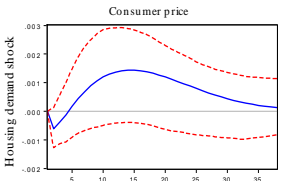

Consumer price

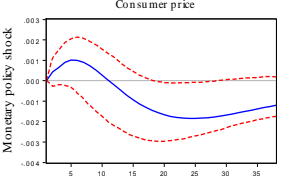

Consumer price

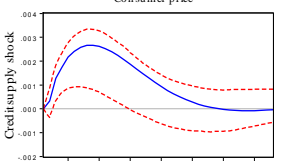

5. Conclusion

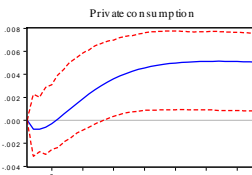

Private con sump tion

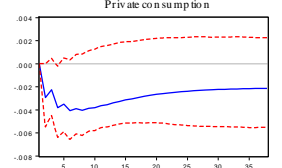

Privale con sumption
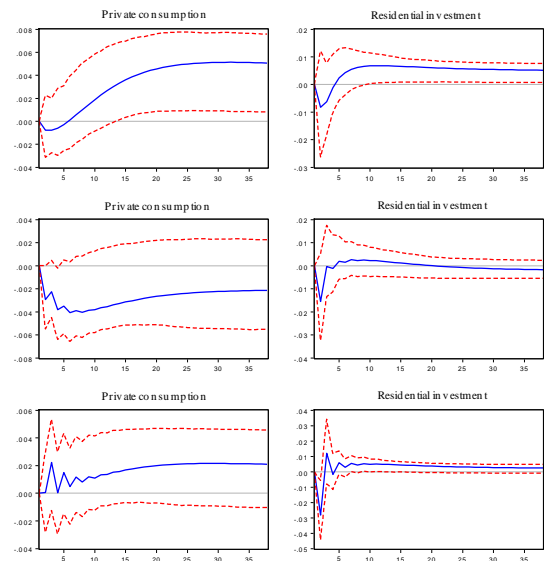

Residen iall in v estme

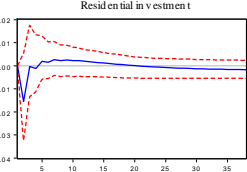

Residen tial in vestme
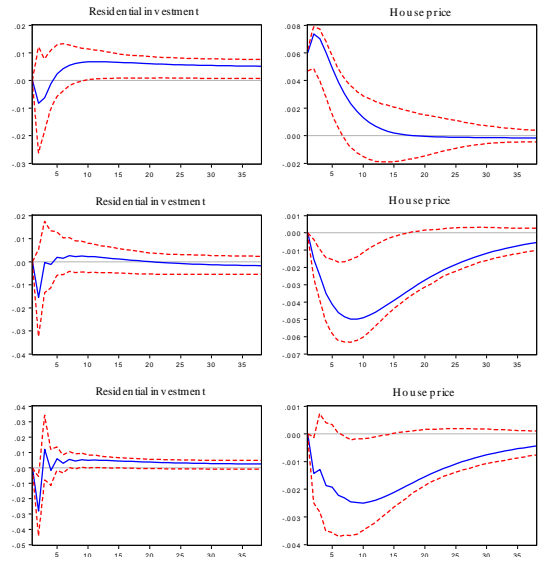

House price

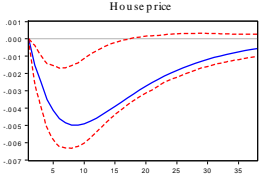

Hou se price
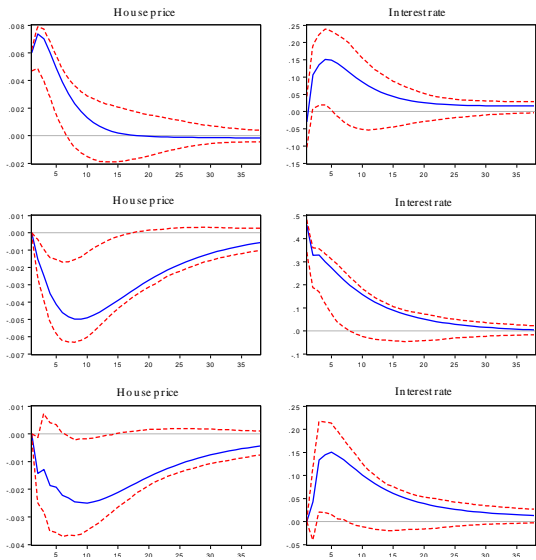

In terest rale

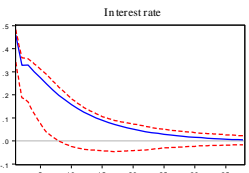

Interestrat
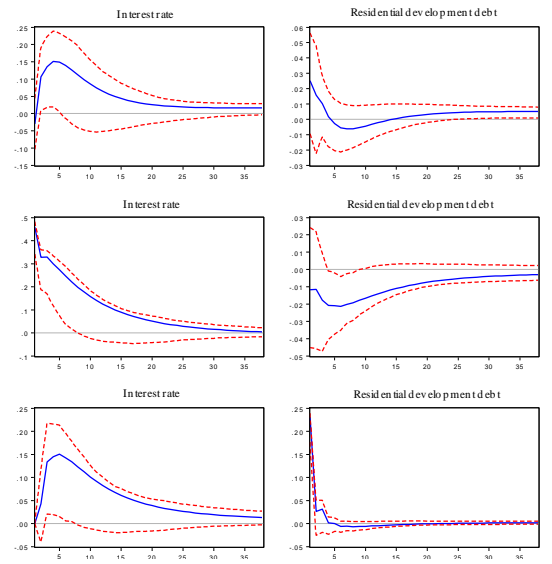

Residen tald dev clopment d

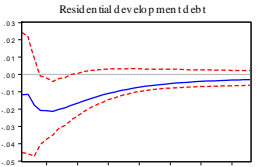

Residen iald dev clop ment des

use price

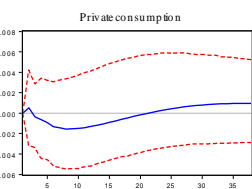

Private consumpio

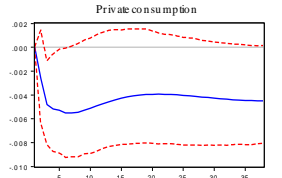

Privale consumpbic
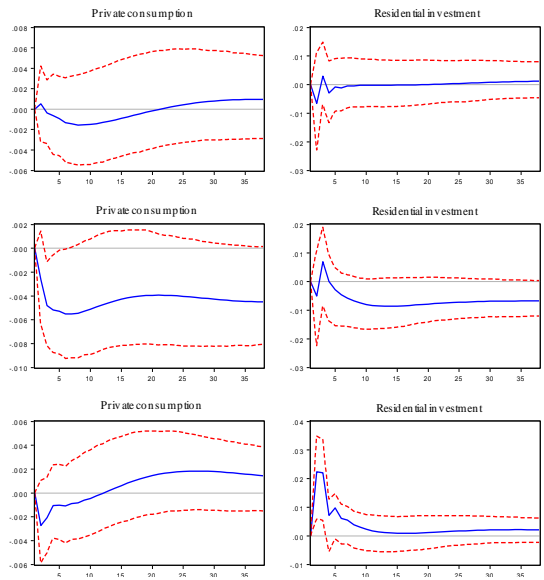

Residential in vestmen

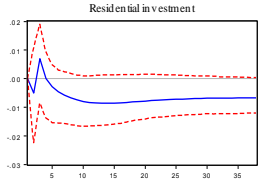

Residen iall in vestmen
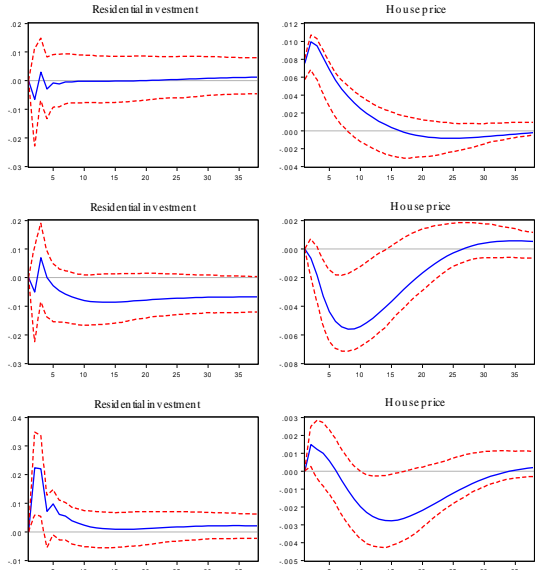

House price

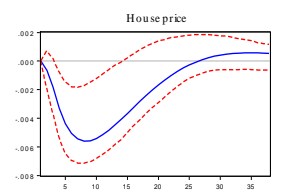

House price
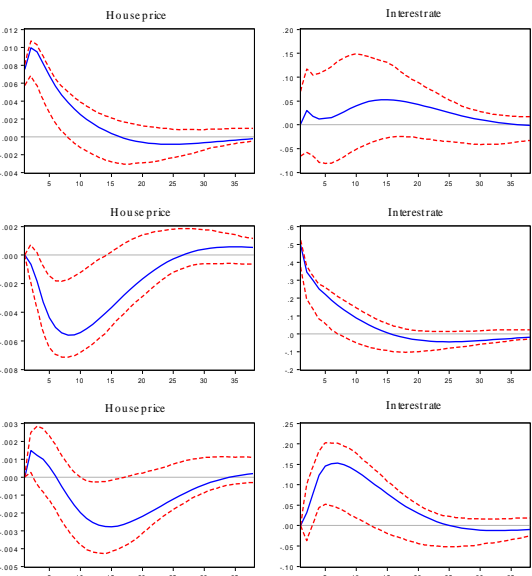

Interestrakt

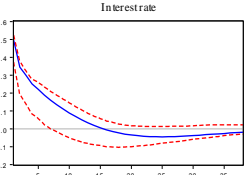

Interestrate
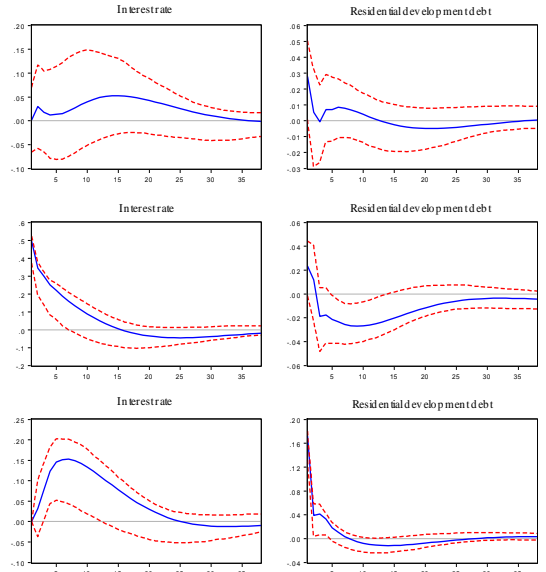

Residen iald dev elopment tebt

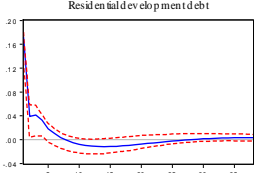

Figure 1. Responses of variables to shocks in four municipalities

This paper presents a systematic empirical analysis of the role of the housing market in the real economy in the four municipalities in China using a SVAR framework. A six-variable SVAR model including consumer prices, private consumption, residential investment, house prices, nominal interest rate and residential development debt provides a plausible description of the behavior of the four municipalities following a house price shock, monetary policy shock and credit supply shock. Impulse responses suggest that the impact of these three shocks is qualitatively similar in the four cities, but the magnitude and timing differ between cities.

The evidence suggests that when a housing demand shock increases house prices, the impact on residential investment and consumption is greater in Beijing and Shanghai than in Tianjin and Chongqing. Monetary policy shocks can have serious effects on house prices. This paper illustrates the important role played by house prices and housing wealth by focusing on transmission to consumption. The results suggest that a proportion of consumption declines due to the effect of housing wealth following monetary policy. This decline is greatest in Beijing and most minimal in Chongqing. Overall, the data show that housing markets might play a bigger role as conduits of monetary policy shocks in some cities than others. The evidence for credit supply shock is less clear-cut. Positive credit supply shocks affect housing market variables in the same way as positive housing demand shocks; they have significant effects on house prices. However, the effects of credit supply on residential investment are statistically insignificant, and the effects on real consumption seem to be more limited.

Our results suggest that raising interest rates could be a policy option for curbing house price appreciation in cities with more developed financial markets, such as Beijing and Shanghai. Further, when adjusting interest rates, the impact on household consumption and the general price levels must be considered., while taking the city-specific characteristics into consideration, future policies should aim to curb surging house prices in first-tier cities and boost sluggish housing markets in other cities. 


\section{Funding}

This work was supported by the Natural Science Foundation of China (NSFC) under grant numbers [71603276] and Science Foundation of China University of Petroleum-Beijing under grant numbers [2462014YJRC056].

\section{Reference}

Amisano, G., \& Giannini, C. (1997). Topics in Structural VAR Econometrics. Berlin: Springer-Verlag. https://doi.org/10.1007/978-3-642-60623-6

Andre, C. (2010). A Bird's Eye View of OECD Housing Markets. OECD, Economics Department, OECD Economics Department Working Papers: 746. https://doi.org/10.1787/5kmlh5qvz1s4-en

Attanasio, O., Leicester, A., \& Wakefield, M. (2011). Do House Prices Drive Consumption Growth? The Coincident Cycles of House Prices and Consumption in the UK. Journal of the European Economic Association, 9(3), 399-435. https://doi.org/10.1111/j.1542-4774.2011.01021.x

Bassanetti, A., \& Zollino, F. (2010). The Effects of Housing and Financial Wealth on Personal Consumption: Aggregate Evidence for Italian Households. In O. de Bandt, T. Knetsch, J. Penalosa \& F. Zollino (Eds.), Housing Markets in Europe: A Macroeconomic Perspective (pp. 307-336): New York and Heidelberg: Springer. https://doi.org/10.1007/978-3-642-15340-2_14

Bian, T. Y., \& Gete, P. (2014). What Drives Housing Dynamics in China? A Sign Restrictions VAR Approach SSRN working paper. https://doi.org/10.1016/j.jmacro.2015.08.004

Bjornland, H. C., \& Jacobsen, D. H. (2010). The Role of House Prices in the Monetary Policy Transmission Mechanism in Small Open Economies. Journal of Financial Stability, 6(4), 218-229. https://doi.org/10.1016/j.jfs.2010.02.001

Bulligan, G. (2010). Housing and the Macroeconomy: The Italian Case. In O. de Bandt, T. Knetsch, J. Penalosa \& F. Zollino (Eds.), Housing Markets in Europe: A Macroeconomic Perspective (pp. 19-38):New York and Heidelberg: Springer. https://doi.org/10.1007/978-3-642-15340-2_2

Calcagno, R., Fornero, E., \& Rossi, M. C. (2009). The Effect of House Prices on Household Consumption in Italy. Journal of Real Estate Finance and Economics, 39(3), 284-300. https://doi.org/10.1007/s11146-009-9187-x

Case, K. E., Quigley, J. M., \& Shiller, R. J. (2005). Comparing Wealth Effects: The Stock Market versus the Housing Market. B.E. Journal of Macroeconomics: Advances in Macroeconomics, 5(1), 1-32. https://doi.org/10.2202/1534-6013.1235

Elbourne, A. (2008). The UK Housing Market and the Monetary Policy Transmission Mechanism: An SVAR Approach. Journal of Housing Economics, 17(1), 65-87. https://doi.org/10.1016/j.jhe.2007.09.002

Erceg, C., \& Levin, A. (2006). Optimal Monetary Policy with Durable Consumption Goods. Journal of Monetary Economics, 53(7), 1341-1359. https://doi.org/10.1016/j.jmoneco.2005.05.005

Ghent, A. C., \& Owyang, M. T. (2010). Is Housing the Business Cycle? Evidence from US Cities. Journal of Urban Economics, 67(3), 336-351. https://doi.org/10.1016/j.jue.2009.11.001

Gilchrist, S. (2002). Houses as Collateral: Has the Link between House Prices and Consumption in the U.K. Changed? Commentary. Federal Reserve Bank of New York Economic Policy Review, 8(1), 179-182. File URL: https://www.newyorkfed.org/medialibrary/media/research/epr/02v08n1/0205gilc.pdf

Giuliodori, M. (2005). The Role of House Prices in the Monetary Transmission Mechanism across European Countries. Scottish Journal of Political Economy, 52(4), 519-543. https://doi.org/10.1111/j.1467-9485.2005.00354.x

Green, R. K. (1997). Follow the Leader: How Changes in Residential and Non-residential Investment Predict Changes in GDP. Real Estate Economics, 25(2), 253-270. https://doi.org/10.1111/1540-6229.00714

Hachicha, A., \& Lee, C. F. (2009). Are Structural VARs with Long-Run Restrictions Useful for Developing Monetary Policy Strategy in Egypt? Review of Pacific Basin Financial Markets and Policies, 12(3), 509-527. Source: RePEc. https://doi.org/10.1142/S0219091509001721

Harvey, A. C. (1999). The econometric analysis of time series: Second edition, Cambridge, Mass.: MIT Press. https://doi.org/10.1016/0164-0704(82)90076-3

Iacoviello, M. (2000). House Prices and The Macroeconomy in Europe : Results from a Structural VAR Analysis. European Central Bank, Working Paper Series: 18. Available at SSRN:https://ssrn.com/abstract=277228

Iacoviello, M., \& Neri, S. (2010). Housing market spillovers: evidence from an estimated DSGE model. American Economic Journal: Macroeconomics, 2(2), 125-164. https://doi.org/10.1257/mac.2.2.125

Jarocinski, M., \& Smets, F. R. (2008). House Prices and the Stance of Monetary Policy. Federal Reserve Bank of St. 
Louis Review, 90(4), 339-365. Available at SSRN:https://ssrn.com/abstract=1120167.

Kilian, L. (1998). Small-Sample Confidence Intervals for Impulse Response Functions. Review of Economics and Statistics, 80(2), 218-230. Source: RePEc. https://doi.org/10.1162/003465398557465

Lastrapes, W. D. (2002). The Real Price of Housing and Money Supply Shocks: Time Series Evidence and Theoretical Simulations. Journal of Housing Economics, 11(1), 40-74. https://doi.org/10.1006/jhec.2002.0309

Ludwig, A., \& Slok, T. (2004). The Relationship between Stock Prices, House Prices and Consumption in OECD Countries. Topics in Macroeconomics, 4(1), 1-26. https://doi.org/10.2202/1534-5998.1114

Magnus, J. R., \& Neudecker, H. (1988). Matrix differential calculus with applications in statistics and econometrics: New York; Chichester; Toronto and Brisbane:Wiley. https://doi.org/10.2307/2290109

Muellbauer, J., \& Murphy, A. (2008). Housing Markets and the Economy: The Assessment. Oxford Review of Economic Policy, 24(1), 1-33. https://doi.org/10.1093/oxrep/grn011

Musso, A., Neri, S., \& Stracca, L. (2011). Housing, Consumption and Monetary Policy: How Different Are the US and the Euro Area? Journal of Banking and Finance, 35(11), 3019-3041. https://doi.org/10.1016/j.jbankfin.2011.04.004

Nanda, A., \& Yeh, J. H. (2014). International Transmission Mechanisms and Contagion in Housing Markets SSRN working paper. https://doi.org/10.2139/ssrn.2420758

Narayan, S., \& Narayan, P. K. (2011). The Importance of Real and Nominal Shocks on the UK Housing Market. International Journal of Business and Economics, 10(3), 219-234. https://doi.org/10.2139/ssrn.2052122

Ncube, M., \& Ndou, E. (2011). Monetary Policy Transmission, House Prices and Consumer Spending in South Africa: An SVAR Approach. Working Paper No.133. African Development Bank. File URL:https://www.afdb.org/fileadmin/uploads/afdb/Documents/Publications/WORKING\%20133\%20Monetary\%2 0Policy\%20Transmission\%20.pdf

Pavlidis, E., Paya, I., Peel, D., \& Spiru, A. M. (2009). Bubbles in House Prices and their Impact on Consumption: Evidence for the US. Lancaster University Management School, Economics Department, Working Papers: 601552. Retrieved from http://eprints.lancs.ac.uk/27889/

Pedram, M., Shirinbakhsh, S., \& Afshar, A. (2011). The Role of House Prices in the Monetary Policy Transmission Mechanism in Iran: SVAR Approach and Counterfactual Simulation. Journal of Advanced Social Research, (1), 214-228.

Peretti, V., Gupta, R., \& Inglesi, L. R. (2012). Do House Prices Impact Consumption and Interest Rate in South Africa? Evidence from a Time-Varying Vector Autoregressive Model. Economics, Management, and Financial Markets, 7(4), 101-120. https://doi.org/10.1177/0972652715584267

Phang, S. Y. (2004). House Prices and Aggregate Consumption: Do They Move Together? Evidence from Singapore. Journal of Housing Economics, 13(2), 101-119. https://doi.org/10.1016/j.jhe.2004.04.003

Porter, N. J., Ahuja, A., Cheung, L., Han, G., \& Zhang, W. (2010). Are house prices rising too fast in China? International Monetary Fund, IMF Working Papers: 10/274. Available at SSRN: https://ssrn.com/abstract=1751386

Porter, N. J., \& Xu, T. (2009). What Drives China's Interbank Market? International Monetary Fund, IMF Working Papers: 09/189. Retrieved from http://www.imf.org/external/pubs/ft/wp/2009/wp09189.pdf

Sims, C. A., Stock, J. H., \& Watson, M. W. (1990). Inference in Linear Time Series Models with Some Unit Roots. Econometrica, 58(1), 113-144. https://doi.org/10.2307/2938337

Vargas, S. C. (2008). Monetary policy and the US housing market: a VAR analysis imposing sign restrictions. Journal of Macroeconomics, 30(3), 977-990. https://doi.org/10.1016/j.jmacro.2007.07.004

\section{Copyrights}

Copyright for this article is retained by the author(s), with first publication rights granted to the journal.

This is an open-access article distributed under the terms and conditions of the Creative Commons Attribution license which permits unrestricted use, distribution, and reproduction in any medium, provided the original work is properly cited. 